\title{
A methodological approach to the assessment of agricultural or- ganizations' resource potential
}

\author{
Myariam Bogapova* \\ Ulyanovsk State Agrarian University, 432017 Ulyanovsk, Russia
}

\begin{abstract}
Improving the efficiency of the resource potential use is of particular importance, since it makes it possible to significantly increase the degree of resource utilization and the efficiency of agricultural production. From this point of view, the study of theoretical, methodological and practical issues of assessing the resource potential, the effectiveness of its use allow one to substantiate the priority directions of development of the agrarian sector of the economy and are extremely important. The study was conducted to identify the level of availability and the degree of efficiency in the resource potential use of agricultural organizations in the Ulyanovsk region. To assess the availability of the resource potential, a system of indicators was used: capital supply, material supply, labor supply, profit, humus content. The conducted study allowed us to identify three groups of municipalities of the Ulyanovsk region with different levels and degrees of efficiency in the resource potential use of agricultural organizations.
\end{abstract}

\section{Introduction}

The problem of evaluating the efficiency of the resource potential used by agricultural organizations is gaining particular significance now, since the current practice of management is indicative of a high degree of uncertainty in the environment of organizations' functioning [1, 2]. In this situation, the study of theoretical and practical issues of assessing the resource potential of agricultural organizations and increasing the efficiency of its use is becoming topical. This study will make it possible to carry out a more rational combination of land, labor and material and technical resources under present day conditions.

\section{Conditions and research methods}

When analyzing the availability and effectiveness of the use of the resource potential of the agrarian sector of the economy, it is necessary to take into account that, in addition to internal factors, the organization's activities are influenced by the conditions and factors in the environment, regardless of the specific organization's activities, but having influence on its operation and requiring the adoption of management decisions. The classification of environmental factors due to their diversity is different and can be based on different principles.

As applied to the agrarian sector of the economy, we propose to consider the following groups of external factors: economic, political, technological, market, social, environmental ones. Each group comprises a set of factors that in one way or another have an impact on the activities of the agricultural organization. These factors are interrelated and overlap, so it is very important to distinguish between them, to determine the place of each of them when studying the effectiveness of the organization. Such a multi-factor assessment will allow us to reveal "bottlenecks" in the process of realizing the resource potential of an organization in the agricultural sector of the economy and identify the main directions of required managerial influences in terms of improving its structure.

A systematic approach serves as the methodological basis for the analysis and assessment of the resource potential of the agrarian sector of the economy. This is connected, first of all, with the fact that we consider the resource potential as a system with certain properties.

To identify the territorial features of the state and trends in the development of the resource potential of the agrarian sector of the economy, we consider it necessary to use a system of methods that comprises, among others, economic and statistical analysis, economic and mathematical modeling, as well as a prognostic analysis. An indispensable condition is the study of the dynamic characteristics of the resource potential of the agricultural sector of the economy, including the use of forecasting methods, regression modeling and cluster analysis.

The use of these research methods in the work will allow us to objectively assess the existing situation, predict further development trends of the regional agrarian economic system, as well as develop adequate management actions [3, 4].

The quality of the results of information and analytical research is largely determined by the initial conditions (information, intellectual and hardware-

$\bar{*}$ Corresponding author: bogapova-marina@ rambler.ru 
software resources) of the functioning management system. Economic-mathematical models are sufficiently universal and give an objective view of the simulated objects and processes.

To apply the methods of modeling the development trends of the agrarian economic system with the aim of using them in a detailed study of the resource potential of the agrarian sector of the regional economy is extremely necessary to maintain the competitiveness of agricultural products at an appropriate level.

Currently, the majority of agricultural producers in the region carry out their activities, relying more on their intuition than on the use of information and analytical methods.

However, despite the acuteness of this problem, at present there is neither a sufficiently developed appropriate methodological toolkit, nor a single system of indicators that takes into account the level of consideration and the degree of development of the resource potential, nor the generally accepted methodological approach to its assessment. In each particular case, their choice depends on the goals and objectives of the study, as well as the level at which analysis and evaluation are made. It also depends on the approach to understanding the essence and content of the formation, development and reproduction of the resource potential, as well as the availability and accessibility of the corresponding statistical information.

Unfortunately, today the state statistics bodies do not conduct regular and informative monitoring of the agrarian sector, based on the results of which it would be possible to obtain an adequate assessment of the resource potential of the agrarian sector of the economy as a whole and of its individual territorial entities, as well as individual agricultural enterprises.

For example, the assessment of the resource potential at the present stage of the development of agrarian relations should also be carried out taking account of the environmental factor. However, the indicators characterizing it do not get an extensive coverage and thus limit the possibilities of analysis and its objectivity.

Practically all the information and analytical techniques used, on the one hand, are not provided with the required information resource, that is, updated, sufficiently complete and comparable data. And on the other hand there is no demand for and necessary intellectual resources for the analysis and assessment of the resource potential of the agricultural sector taking account of various regional levels and specific features $[5,6]$.

The results of the generalization of the existing methodological approaches to the assessment of the resource potential are given in Table 1 .

As we can see from the data of Table 1, with the help of the methodological approaches considered, one can obtain an economic, economic-statistical or economicmathematical assessment of the resource potential.

The identified methodological approaches are characterized by the use of various systems of indicators and methodological tools [7-9].
Table 1. Methodological approaches to the assessment of the resource potential of the agricultural sector of the economy

\begin{tabular}{|c|c|c|c|c|c|}
\hline \multicolumn{2}{|c|}{ Sign } & $\begin{array}{c}\text { Specific feature } \\
\text { of essence }\end{array}$ & $\begin{array}{l}\text { Type of } \\
\text { the re- } \\
\text { source } \\
\text { potential } \\
\text { assess- } \\
\text { ment }\end{array}$ & $\begin{array}{c}\text { Re- } \\
\text { search } \\
\text { methods }\end{array}$ & $\begin{array}{l}\text { In- } \\
\text { di- } \\
\text { ca- } \\
\text { tor }\end{array}$ \\
\hline \multirow{5}{*}{ 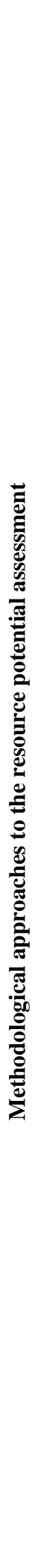 } & 离 & $\begin{array}{l}\text { Deviation of the } \\
\text { actual from the } \\
\text { standard value of } \\
\text { the individual } \\
\text { components of the } \\
\text { resource potential, } \\
\text { which does not } \\
\text { involve taking } \\
\text { account of the real } \\
\text { interrelations } \\
\text { between resources }\end{array}$ & 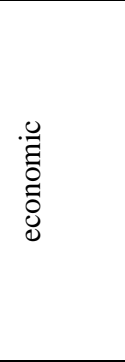 & $\begin{array}{l}\text { regres- } \\
\text { sion } \\
\text { analysis, } \\
\text { compu- } \\
\text { tational } \\
\text { and } \\
\text { con- } \\
\text { struc- } \\
\text { tive, } \\
\text { balance }\end{array}$ & 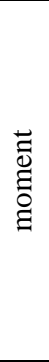 \\
\hline & 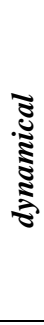 & $\begin{array}{l}\text { The study of the } \\
\text { state of the re- } \\
\text { source potential of } \\
\text { an agricultural } \\
\text { organization (in- } \\
\text { cluding element } \\
\text { by element) over } \\
\text { time in connection } \\
\text { with production } \\
\text { indicators }\end{array}$ & 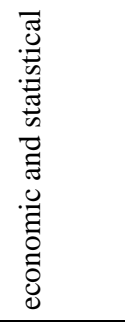 & $\begin{array}{l}\text { correla- } \\
\text { tion } \\
\text { analysis, } \\
\text { regres- } \\
\text { sion } \\
\text { analysis, } \\
\text { index } \\
\text { analysis }\end{array}$ & : \\
\hline & 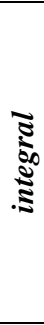 & $\begin{array}{l}\text { The study is con- } \\
\text { ducted on an } \\
\text { integral assess- } \\
\text { ment to compare } \\
\text { the planned and } \\
\text { actual indicators, } \\
\text { regardless of the } \\
\text { agricultural organ- } \\
\text { ization's speciali- } \\
\text { zation }\end{array}$ & 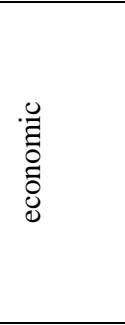 & $\begin{array}{c}\text { index } \\
\text { analysis, } \\
\text { design } \\
\text { analysis }\end{array}$ & 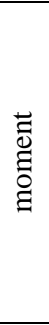 \\
\hline & 音 & $\begin{array}{l}\text { Dependence RP = } \\
\text { PP + S (R), where } \\
\text { RP - resource } \\
\text { potential of the } \\
\text { agricultural organ- } \\
\text { ization, PP - pro- } \\
\text { duction potential } \\
\text { of the agricultural } \\
\text { organization, } \mathrm{S} \\
\text { (R) - stocks (re- } \\
\text { serves), provides } \\
\text { an opportunity to } \\
\text { study the internal } \\
\text { (production) and } \\
\text { external (unused } \\
\text { resource) struc- } \\
\text { tures of the re- } \\
\text { source potential }\end{array}$ & 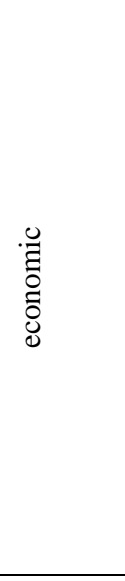 & $\begin{array}{l}\text { compu- } \\
\text { tational, } \\
\text { econom- } \\
\text { ic, sta- } \\
\text { tistical, } \\
\text { regula- } \\
\text { tory, } \\
\text { model- } \\
\text { ing }\end{array}$ & 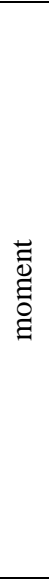 \\
\hline & 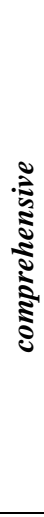 & $\begin{array}{l}\text { It is carried out } \\
\text { taking into } \\
\text { account the } \\
\text { specialization of } \\
\text { the agricultural } \\
\text { organization for } \\
\text { the integral } \\
\text { assessment of the } \\
\text { resource potential } \\
\text { in the context of } \\
\text { influence factors } \\
\text { and the strength of } \\
\text { their influence on } \\
\text { deviations of } \\
\text { standard and } \\
\text { actual values }\end{array}$ & $\begin{array}{l}\text { econom- } \\
\text { ic and } \\
\text { mathe- } \\
\text { matical }\end{array}$ & $\begin{array}{c}\text { vector } \\
\text { algebra } \\
\text { econom- } \\
\text { ic- } \\
\text { statisti- } \\
\text { cal }\end{array}$ & 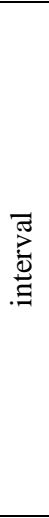 \\
\hline
\end{tabular}


Determining the level of agricultural organizations' resource potential and the efficiency degree of its use with the help of the proposed methodological approach is supposed to be carried out in several stages. At the first stage, a system of quantitative indicators is formed to assess the availability of agricultural organizations' resources.

At the second stage, individual indicators of the level of the resource potential of agricultural organizations are determined for each of the factors of production (labor, land, capital, entrepreneurial abilities).

To do this, it is necessary to use the group efficiency index $\left(I_{e}\right)$ which is given as the arithmetic average value of the single indices $\left(i_{\varepsilon}\right)$ :

$$
\mathrm{I}_{\mathrm{e}}=\left(\mathrm{i}_{\mathrm{e} 1}+\mathrm{i}_{\mathrm{e} 2}+\mathrm{i}_{\mathrm{e} 3}+\ldots .+\mathrm{i}_{\mathrm{en}}\right) / \mathrm{n},
$$

where $n-$ the number of single indices of the level of resource potential.

To calculate the level of the resource potential of agricultural organizations, we consider it appropriate to use the following system of indicators:

- labor supply per 100 ha of arable land, thousand rubles;

- capital supply per 100 ha of arable land, thousand rubles;

- material provision per 100 ha of arable land, thousand rubles;

- $\quad$ profit per 100 ha of arable land, thousand rubles;

- $\quad$ humus content, \%.

At the third stage the efficiency indices of the resource potential use in the agrarian sector of the economy is calculated for all five factors of production. To this end, it is required to make use of the group index of efficiency $\left(I_{\varepsilon}\right)$, determined as the arithmetic mean value of single indices $\left(i_{\varepsilon}\right)$ (formula 1 ).

We propose to assess the efficiency of the resource potential use in view of the following indicators: labor productivity, production volume per 100 hectares of arable land, the volume of production per 100 hectares of arable land, the capital-labor ratio, capital turnover, the ratio of profit to the wage fund, the ratio of the executive's wage fund to the wage fund of workers.

Both when calculating the group level index and when calculating the group index of the efficiency of the resource potential used by an agricultural organization, it is necessary to take into account that if an increase in the value of the index entails an increase in the ranking of the municipality, then the single index is determined by the formula (2):

$$
\mathrm{i}_{\mathrm{e}}=\mathrm{i}_{\mathrm{ej}} / \overline{i_{e}},
$$

where $i_{e j}$ - the value of the index of the $j$ municipality, $\overline{l_{e}}$ - the mean value of the index in the set of municipalities.

If the increase in the value of the index contributes to a decrease in the ranking of the municipality, then a single index is calculated in the reverse order:

$$
\mathrm{I}_{\mathrm{e}}=\overline{i_{e}} / \mathrm{i}_{\mathrm{ej}} \text {. }
$$

At the fourth stage, it is necessary to calculate the integral indicators of the level of resource potential and the efficiency of its use as arithmetic mean values of group indices.

\section{Results and discussion}

When selecting indicators, not only the quantitative component was taken into account, but also the qualitative one, reflecting the efficiency of using certain types of resources, the provision of municipalities with these types of resources [10-14].

As a result of calculations, the values of group and integral indices of the level and efficiency of the resource potential used by agricultural organizations in the region have been obtained, which are given in Table 2 .

The ranking of municipalities of the Ulyanovsk region in terms of the resource potential showed that the index varies from 0.36 in the Inzensky to 2.69 in the Cherdaklinsky district (Figure 1).

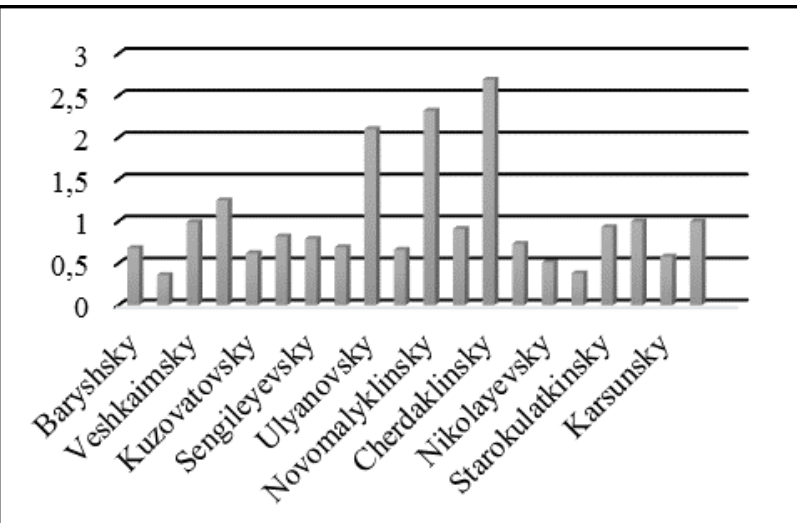

Fig.1. The ranking of municipalities of the Ulyanovsk region in terms of resource potential (according to the data of 2017)

Table 2. Group and integral indicators of the level of agricultural or-

\begin{tabular}{|c|c|c|c|}
\hline $\begin{array}{l}\text { Name of the } \\
\text { municipality }\end{array}$ & $\begin{array}{l}\text { Group } \\
\text { index of } \\
\text { the level } \\
\text { of re- } \\
\text { source } \\
\text { potential }\end{array}$ & $\begin{array}{l}\text { Group } \\
\text { index of } \\
\text { the effi- } \\
\text { ciency of } \\
\text { the re- } \\
\text { source } \\
\text { potential } \\
\text { use }\end{array}$ & $\begin{array}{c}\text { Integral } \\
\text { index of } \\
\text { the level } \\
\text { and effi- } \\
\text { ciency of } \\
\text { the re- } \\
\text { source } \\
\text { potential } \\
\text { use }\end{array}$ \\
\hline Baryshsky & 0.68 & 0.68 & 0.68 \\
\hline Inzensky & 0.36 & 0.60 & 0.48 \\
\hline Veshkaimsky & 0.99 & 0.87 & 0.93 \\
\hline Sursky & 1.25 & 1.03 & 1.14 \\
\hline Kuzovatovsky & 0.62 & 0.64 & 0.63 \\
\hline Tsilninsky & 0.82 & 1.01 & 0.92 \\
\hline Sengileyevsky & 0.79 & 0.75 & 0.77 \\
\hline Mainsky & 0.69 & 0.98 & 0.83 \\
\hline Ulyanovsky & 2.10 & 1.67 & 1.88 \\
\hline Melekessky & 0.66 & 0.71 & 0.69 \\
\hline Novomalyklinsky & 2.32 & 1.34 & 1.83 \\
\hline Staromainsky & 0.91 & 0.99 & 0.95 \\
\hline Cherdaklinsky & 2.69 & 1.04 & 1.86 \\
\hline Radischevsky & 0.73 & 0.79 & 0.76 \\
\hline Nikolayevsky & 0.51 & 0.86 & 0.68 \\
\hline Pavlovsky & 0.38 & 0.84 & 0.61 \\
\hline Starokulatkinsky & 0.93 & 0.65 & 0.79 \\
\hline Novospassky & 1.00 & 1.07 & 1.03 \\
\hline Karsunsky & 0.58 & 0.59 & 0.59 \\
\hline Terengulsky & 1.00 & 0.99 & 0.99 \\
\hline
\end{tabular}
ganizations' resource potential and the efficiency of its use in municipalities of the Ulyanovsk region according to data for 2017 
The ranking of municipalities of the region according to the efficiency of resource potential use in the agrarian sector of the economy allowed us to establish that the index varies from 0.59 in the Karsunsky district to 1.64 in the Novomalyklinsky district.

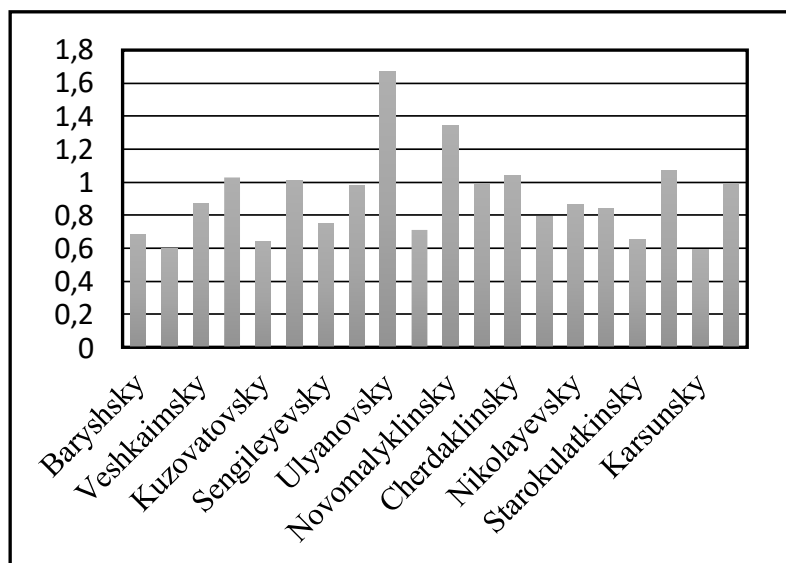

Fig. 2. Ranking of municipalities, depending on the effectiveness of the resource potential use

At the fifth stage, on the basis of the obtained integral index of the level and the efficiency of resource potential used by agricultural organizations in the region, we will single out 3 groups of municipalities (Figure 3 ).

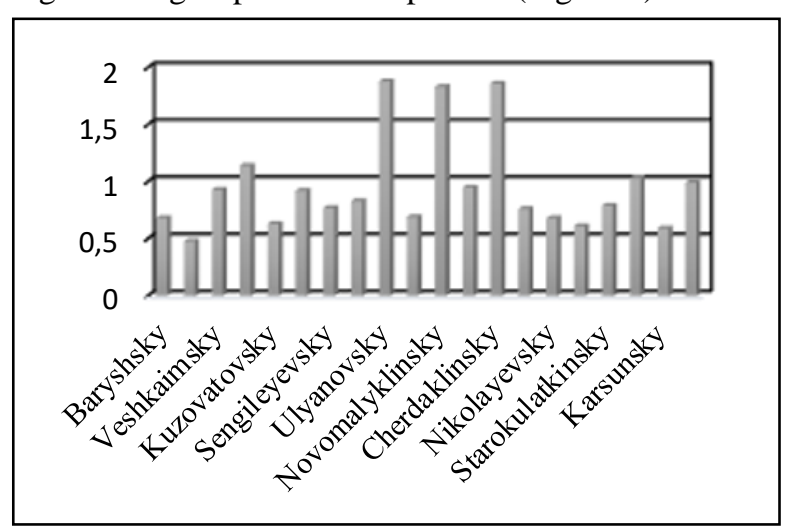

Fig. 3. Groups of the Ulyanovsk region municipalities, depending on the value of the integral indicator

Municipalities are grouped into three segments based on vertical and horizontal boundaries. The value of the vertical border $\left(\mathrm{q}_{\mathrm{k}}\right)$ is determined by the formula:

$$
\mathrm{q}_{\mathrm{k}}=\left(\mathrm{I}_{\operatorname{maxk}}+\mathrm{I}_{\operatorname{mink}}\right) / 2 \text {, }
$$

where $I_{\max }$-the maximum value of the integral index of the level and efficiency of the resource potential used by agricultural organizations, ${ }^{I} \min k-$ the minimum value of the integral index.

For instance, the first group is comprised of: the Ulyanovsk, Cherdaklinsky, Novomalyklinsky districts. The second group consisted of: the Sursky, Novospassky, Veshkaimsky, Tsilninsky, Staromainsky, Terengulsky districts. The third group includes the following municipalities: the Melekessky, Baryshsky, Inzensky, Mainsky, Kuzovatovsky, Sengileyevsky, Starokulatkinsky, Nikolayevsky, Pavlovsky, Karsunsky, Radischevsky districts (Table 3).
Table 3. Grouping of municipalities of the Ulyanovsk region, depending on the value of the integral index of the level and efficiency of the resource potential use

\begin{tabular}{|c|c|c|}
\hline 1 group & 2 group & 3 group \\
\hline $\begin{array}{c}\text { Municipalities } \\
\text { with a high level } \\
\text { and efficient use } \\
\text { of resource poten- } \\
\text { tial }\end{array}$ & $\begin{array}{l}\text { Municipalities } \\
\text { with an average } \\
\text { level and effi- } \\
\text { ciency of the } \\
\text { resource poten- } \\
\text { tial use }\end{array}$ & $\begin{array}{l}\text { Municipalities } \\
\text { with a low level } \\
\text { and efficiency of } \\
\text { the resource po- } \\
\text { tential use }\end{array}$ \\
\hline $\begin{array}{c}\text { Mean value of the } \\
\text { integral index } \\
1.86\end{array}$ & $\begin{array}{l}\text { Mean value of } \\
\text { the integral } \\
\text { index } 6.99\end{array}$ & $\begin{array}{c}\text { Mean value of the } \\
\text { integral index } \\
0.68\end{array}$ \\
\hline $\begin{array}{l}\text { Ulyanovsky, } \\
\text { Cherdaklinsky, }\end{array}$ & $\begin{array}{c}\text { Sursky, } \\
\text { Novospassky, }\end{array}$ & $\begin{array}{l}\text { Melekessky, } \\
\text { Baryshsky, }\end{array}$ \\
\hline 1 group & 2 group & 3 group \\
\hline $\begin{array}{l}\text { Municipalities } \\
\text { with a high level } \\
\text { and efficient use } \\
\text { of resource } \\
\text { potential }\end{array}$ & $\begin{array}{l}\text { Municipalities } \\
\text { with an average } \\
\text { level and } \\
\text { efficiency of the } \\
\text { resource } \\
\text { potential use }\end{array}$ & $\begin{array}{c}\text { Municipalities } \\
\text { with a low level } \\
\text { and efficiency of } \\
\text { the resource po- } \\
\text { tential use }\end{array}$ \\
\hline $\begin{array}{c}\text { Mean value of the } \\
\text { integral index } \\
1.86\end{array}$ & $\begin{array}{l}\text { Mean value of } \\
\text { the integral } \\
\text { index } 6.99\end{array}$ & $\begin{array}{c}\text { Mean value of the } \\
\text { integral index } \\
0.68\end{array}$ \\
\hline Novomalyklinsky & $\begin{array}{l}\text { Veshkaimsky, } \\
\text { Tsilninsky, } \\
\text { Staromainsky, } \\
\text { Terengulsky }\end{array}$ & $\begin{array}{c}\text { Inzensky, Main- } \\
\text { sky, } \\
\text { Kuzovatovsky, } \\
\text { Sengileyevsky, } \\
\text { Starokulatkinsky, } \\
\text { Nikolayevsky, } \\
\text { Pavlovsky, } \\
\text { Karsunsky, Ra- } \\
\text { dischevsky }\end{array}$ \\
\hline
\end{tabular}

\section{Conclusion}

Thus, the proposed methodological approach allows us to determine the level and efficiency of the resource potential use of organizations in the agricultural sector of the economy. With the help of the proposed methodology for assessing the level and efficiency of using the resource potential by organizations in the agricultural sector of the economy, it is possible to give a general description of the resources that the territory under study possesses and compare various territorial entities with each other, identifying their strengths and weaknesses.

\section{References}

1. T. A. Dozorova, M.R. Bogapova, Efficiency of the resource potential use: the assessment and areas for improvement Kazan Agrarian Bulletin 3, 152-156 (2018)

2. T.A. Dozorova, N.M. Neif, Methodological approaches to the assessment of the effectiveness of the use of resource potential by agricultural organizations Bulletin of Ulyanovsk State Agricultural Academy 3(23), 132-138 (2013) 
3. V.P. Kandilov, Human potential as a factor of the resource potential of the territory in Proc. of AllRussian Scientific Conf. "All-Russian Population Census as an Informational and Statistical Base for Strategizing Social and Economic Development of the State and Regions" 253-270 (Penza, 2008)

4. M.A. Komarov, A.N. Romanov, Eds., Resource potential of economic growth 567 (Path of Russia, Moscow, 2002)

5. V.A. Kundius, The Economy of the AIC: study guide 669 (Altai State Agrarian University, Barnaul, 2007)

6. V.V. Skobara, V.V. Podkopaev, Analysis stages of economic potential of agricultural enterprises Transactions of the Russian Academy of Entrepreneurship 42, 260-267 (2015)

7. S.Yu. Steksova, Methodology for determining the resource potential of an enterprise Management in Russia and abroad 4 (2011)

8. E.A. Tarasova, E.A. Smirnova, M.V. Postnova, The study of the state of rural labor resources and their employment in the agrarian sector of the Ulyanovsk region The Agricultural Economy of Russia 10, 52$56(2018)$
9. M.L. Yashina, N.M. Neif, T.V. Treskova, Development of a regional agro-industrial production and education cluster in Proc. of the III Int. Scientific-Methodological and Practical Conf. "Integrated Development of Rural Areas and Innovative Technologies in the Agro-Industrial Complex 232-235 (2018)

10. The official website of the Unified Interagency Information and Statistical System (UMISS) Retrieved from: https://fedstat.ru:8443/

11. The official site of the Federal State Statistics Service of the Russian Federation Retrieved from: www.gks.ru

12. The statistical yearbook. Ulyanovsk region, 2018 : Stat.sb 140 (Ulyanovskstat, Ulyanovsk, 2017)

13. Ulyanovsk region in numbers. A concise statistical book 140 (Ulyanovskstat, Ulyanovsk, 2017)

14. The national report on the progress and implementation results in 2013-2017. The State Program for the Development of Agriculture and Regulation of Agricultural Products, Raw Materials and Food Markets for 2013-2020. 